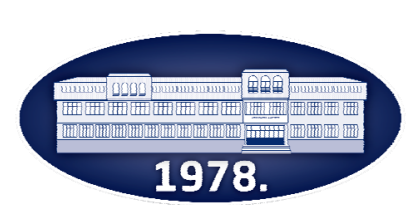

Publisher: Faculty of Agronomy Čačak

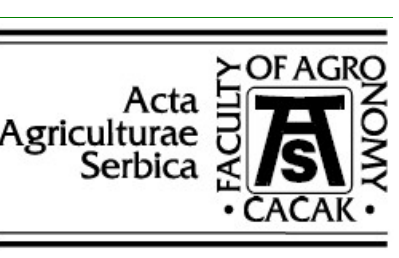

\title{
Grain yield potential of spring dry pea varieties
}

\author{
Branko Milošević*, Vojislav Mihailović, Đura Karagić, Sanja Vasiljević, Dragan Milić, \\ Gordana Petrović, Snežana Katanski, Dalibor Živanov, Aleksandar Mikić, Ivica Đalović, \\ Anja Dolapčev, Ana Uhlarik
}

Institute of Field and Vegetable Crops, Maksima Gorkog 30,21000 Novi Sad, Serbia

*Corresponding author: branko.milosevic83@gmail.com

Received 3 March 2020; Accepted 2 November 2020

\begin{abstract}
A B S T R A C T
Field peas are mostly used for animal nutrition in the Balkan region and in the countries of the former USSR, while in the countries of Western Europe, Canada, the USA and the Middle East they are mostly used for human nutrition. Over three years (2010-2012), the yield and grain yield components of the most widespread field pea varieties were examined. The lowest number of plants was determined in 'NS Junior' intended for combined use (65 plants/m2), while 'Dukat' and 'Partner' had 88 and 85 plants $/ \mathrm{m} 2$ on average, respectively. The average stem height was $158 \mathrm{~cm}$ for 'NS Junior', and 65 and $70 \mathrm{~cm}$ for 'Dukat' and 'Partner', respectively. 'Dukat' (4846 kg/ha) and 'Partner' (4521 kg/ha) had significantly higher grain yields compared with 'NS Junior' (2717 kg/ha). The content of crude protein in the grain was highest in 'NS Junior' (27.6\%), while 'Dukat' and 'Partner' had lower contents (23-25\%).

Keywords: pea for fodder and grain, variety, grain yield, crude protein content.

\section{И 3 В $О$ Д}

Протеински грашак се углавном користи за исхрану животиња у нашем региону и у земљама бившег СССР-а, док се у земљама западне Европе, Канаде, САД-а и Блиског истока највише користи за исхрану људи. Током три године (20102012) испитиване су компоненте приноса и принос зрна најраспрострањенијих сорти протеинског грашка. Најмањи број биљака утврђен је код сорте НС Јуниор, намењене за комбиновану употребу (65 биљака / m2), док су сорте Дукат и Партнер имале у просеку 88 и 85 биљака / m2. Просечна висина стабљике за сорту НС Јуниор износила је 158 сm, а за сорте Дукат и Партнер 65 и $70 \mathrm{~cm}$. Сорте Дукат (4846 kg / ha) и Партнер (4521 kg / ha) имале су знатно већи принос зрна у поређењу са сортом НC Јуниор (2717 kg / ha). Садржај сирових протеина у зрну био је највећи код сорте НС Јуниор $(27,6 \%)$, док су сорте Дукат и Партнер имале између 23 и $25 \%$.
\end{abstract}

Кључне речи: грашак за крму и зрно, сорта, принос, садржај сирових протеина.

\section{Introduction}

Dry pea (Pisum sativum L.) belongs to the Fabaceae family (legumes), which consists of three subfamilies of about 15,000 species, differing in morphological characteristics, growing area and economic importance (Denarie et al., 1992). Pea is characterized by great genetic diversity, according to the morphological composition of varieties with leaves (conventional) and those without leaves (with tendrils of the so-called afila type), indeterminate and determinate stem growth, and very early and late maturity. There are winter and spring varieties. Seeds are different in color, shape and size. Pea varieties can be classified as garden peas, used as vegetables; field peas, used for the production of dry grain for food; and forage peas, grown primarily for green fodder.

Dry pea is grown in the world at 7,600,000 ha, and its production volume reaches 14,360,000 t (FAOSTAT, 2016). A few years ago, Canada had the largest acreage of dry pea $(1,697,000 \mathrm{ha})$, and was its largest producer and importer. In Europe as a whole, the largest producers of field pea are Russia $(1,039,900 \mathrm{ha})$ and Ukraine $(238,700 \mathrm{ha})$, and in the European Union:
France $(216,000 \mathrm{ha})$ and Spain $(174,000 \mathrm{ha})$. Forage pea is well adapted to the agro-environmental conditions of Serbia, and particularly good results are achieved in the regions of Vojvodina and central Serbia.

Field pea can produce dry grain yields of more than 6 t/ha (Mikić et al., 2007, Mihailović et al., 2010). The average yield of crude fodder proteins reaches $1,900 \mathrm{~kg} / \mathrm{ha}$ in winter varieties and more than 1,700 $\mathrm{kg} / \mathrm{ha}$ in spring varieties. The newly developed domestic varieties of dry pea: 'Partner', 'Kristal' and 'Dukat', have an average yield of crude protein between $1,400 \mathrm{~kg} / \mathrm{ha}$ and 1,500 kg/ha (Mihailović et al., 2010). North America increased its share primarily in the production of dry pea and lentil. Europe, once the largest producer of dry pea, saw a sharp decline in the overall production of pulses. Although Asia remained a major producer of many pulses, its share in global production declined between 2001 and 2014 (Rawal and Navarro, 2019). Pea grains contain a large amount of protein, amino acids, sugars, carbohydrates, vitamins $\mathrm{A}$ and $\mathrm{C}$, calcium and phosphorus, and are therefore widely used (Jovičić et al., 2010). 
The aim of the research was to determine the yield and grain yield components, as well as the grain quality of the leading varieties of spring dry pea in Serbia.

\section{Material and methods}

The trial was conducted during 2010-2012 in the experimental field of the Institute of Field and Vegetable Crops, Novi Sad at Rimski Šančevi. The field trial was set up according to a randomized block system in four replicates. The size of the basic plot was 18 square meters $\left(6 \times 3 \mathrm{~m}^{2}\right)$. The distance between the rows in the plot was $20 \mathrm{~cm}$, and therefore each plot had 15 rows.

Three dominant varieties of spring dry pea were included in the trials: 'NS Junior', 'Dukat' and 'Partner'. These varieties represent the three types of field pea that are grown on the largest area in Serbia.

'NS JUNIOR' is a spring pea variety for combined use, i.e. for forage and grain production. The plants are between 125 and $145 \mathrm{~cm}$ in height, of indeterminate type, with a high proportion of leaves in the total plant biomass and white flowers. The variety has a genetic potential for grain yield of $5 \mathrm{t} / \mathrm{ha}$, with a crude protein content of up to $28 \%$. The most common variety of spring pea in Serbia.

'DUKAT' is a medium early, high-yielding variety of spring dry pea, of determinate type, $50-75 \mathrm{~cm}$ in height, and with an ordinary leaf type. It is less tolerant to lodging. In the upper half of the plant, it forms 8-12 pods with 5-7 large grains.

'PARTNER' is a very early variety of spring dry pea for grain production. The length of the growing season of this variety is 80-85 days. It shows minimal tendency to lodging, plant height is $60-80 \mathrm{~cm}$, of the afila leaf type and with white flowers.

The following characteristics of the pea crop were determined and analyzed:

Seed yield components: number of plants per unit area, plant height $(\mathrm{cm})$, number of branches, number of internodes, plant height to first pod $(\mathrm{cm})$, number of pods per plant, number of grains per pod and weight of 1000 grains.

Grain yield.

The analysis of grain yield components was performed on 20 plants from the central rows of each plot, at the stage of physiological maturity of the grain, just before the harvest. The number of plants per unit area was determined by counting plants per square meter. The height of plants was measured from the base to the top of the stem. The number of internodes was determined in the main stem. The height to the first pod was determined from the base of the stem to the first pod.

\section{Results and Discussion}

Crop density is a very significant component of yield, as it explains $68-70 \%$ of the variation in pea seed yield (Mera, 1989). The average number of pea plants in the harvest of 80 plants per $\mathrm{m}^{2}$ was achieved in all the varieties tested. The lowest number of plants per $\mathrm{m}^{2}$ was achieved by 'NS Junior', which had the highest potential for branching (Tab. 1). The variety with indeterminate stem growth, 'NS Junior', had the smallest number of plants per unit area ( 66 plants $/ \mathrm{m}^{2}$ ) compared with the varieties with determinate stem growth, 'Dukat' and 'Partner', whose values were 88 and 85 plants $/ \mathrm{m}^{2}$, respectively. The yield of grain increased with increasing crop density until the optimum was reached. Moot and McNeil (1995) found that the yield of both pea biomass and pea grain doubled by increasing crop density from 9 to 100 plants per $\mathrm{m}^{2}$. Further increase in crop density up to 400 plants per $\mathrm{m}^{2}$ did not increase grain yield. Thus, after reaching the optimum crop density, no further increase in grain yield can be expected. Increasing crop density augments the susceptibility of plants to lodging, which negatively affects grain yield (Pullan and Hebblethwwaite 1990). On the other hand, Sawicki et al. (2000) recommended 100-120 plants per $\mathrm{m}^{2}$ for optimal density for varieties of the afila leaf type. The optimal crop density for providing conditions for maximum grain yield is between 70-140 plants per $\mathrm{m}^{2}$. However, the lower number of plants could be compensated by increasing the number of pods per plant (Heath et al., 1991). However, by reducing crop density below 70 plants per $\mathrm{m}^{2}$, the risk of reducing grain yield is significantly increased.

The number of plants per unit area is the first and most significant component of yield. For 'NS Junior', during three years of testing, the number of plants per square meter ranged from 56 to 77 , giving an average of 66. This variety is intended for combined use, i.e. for the production of fodder and grain because it has a tall stem $(140-160 \mathrm{~cm})$ and a large proportion of leaves in the total biomass yield. 'Dukat' and 'Partner' are typical dry pea varieties, with a stem height of 60 to $85 \mathrm{~cm}$, which was confirmed in our three-year experiment. The number of plants in 'Dukat'ranged from 77 to 96, resulting in an average of 88 . Similar results were obtained for 'Partner', with the range of 83-88 plants per square meter and an average of 85 (Tab. 1). Thus, 'Dukat' and 'Partner', intended for grain production, should have $100-120$ plants per square meter, which is considered the optimal set, as confirmed by numerous studies (Sawicki et al., 2000).

The average plant height of the tested varieties of dry pea was $97.7 \mathrm{~cm}$. The increased susceptibility to lodging of the variety of indeterminate stem growth was due to higher plant height, greater internode length and larger plant biomass. 'NS Junior' had significantly taller plants, with an average of $158.0 \mathrm{~cm}$, compared with the varieties with a determinate stem growth 'Dukat' $(65.3 \mathrm{~cm})$ and 'Partner' $(69.9 \mathrm{~cm})$ (Tab. 1).

The number of branches per plant is a good criterion for selecting productive pea genotypes. The indeterminate growth variety, 'NS Junior', had significantly more pronounced branching (1.57 branches) than 'Dukat' (1.03 branches) and 'Partner' (1.07), thus compensating for a smaller number of plants per unit area, which is in concordance with the results of more research (Spies et al., 2010; Yucel, 2013). In sparse stands, pea plants intensify branching from the base of the stem, thus prolonging the flowering period and maturation. 
Table 1.

Average values of yield components of NS pea varieties for the period 2010-2012 at Rimski Šančevi

\begin{tabular}{|l|l|l|l|l|l|l|l|l|l|l|}
\hline \multirow{2}{*}{ Traits } & \multicolumn{3}{l}{ NS Junior } & \multicolumn{2}{l}{ Dukat } & \multicolumn{2}{l}{ Partner } & \multirow{2}{*}{ Average } \\
\cline { 2 - 12 } & 2010 & 2011 & 2012 & 2010 & 2011 & 2012 & 2010 & 2011 & 2012 & \\
\hline Number of plants/m² & 66 & 77 & 56 & 96 & 91 & 77 & 88 & 83 & 85 & 79.8 \\
\hline Plant height (cm) & 160 & 155 & 158 & 75 & 61 & 59 & 78 & 70 & 60 & 97 \\
\hline Number of branches & 1.5 & 1.7 & 1.5 & 1.0 & 1.1 & 1.0 & 1.1 & 1.1 & 1.0 & 1.22 \\
\hline Number of internodes & 22.1 & 26.1 & 21.8 & 17.2 & 17.9 & 16.4 & 18.0 & 16.7 & 16.0 & 19.1 \\
\hline $\begin{array}{l}\text { Plant height to first } \\
\text { pod (cm) }\end{array}$ & 106 & 99 & 97 & 39 & 37 & 27 & 45 & 42 & 32 & 58 \\
\hline $\begin{array}{l}\text { Number of pods per } \\
\text { plant }\end{array}$ & 9.2 & 11.4 & 16.8 & 9.3 & 8.6 & 11.6 & 8.1 & 9.3 & 10.0 & 10.5 \\
\hline $\begin{array}{l}\text { Number of grains per } \\
\text { pod }\end{array}$ & 4.6 & 3.8 & 4.0 & 4.9 & 5.0 & 4.7 & 3.9 & 3.8 & 3.8 & 4.4 \\
\hline $\begin{array}{l}\text { Weight of 1000 grains } \\
\text { (g) }\end{array}$ & 155 & 131 & 156 & 221 & 220 & 255 & 215 & 210 & 216 & 198 \\
\hline
\end{tabular}

The largest number of internodes was found in the late-growing variety of indeterminate growth 'NS Junior' (23.3). Among the varieties of determinate stem growth, the number of internodes was 17.2 in 'Dukat', and 16.9 in 'Partner'.

Significant differences were found in stem height to the first pod between the tested varieties of dry pea. The highest average values for the tested trait were determined for 'NS Junior' $(101.1 \mathrm{~cm})$, a very lategrowing variety of indeterminate stem growth. In the determinate stem-type and afila-leaf-type cultivar 'Partner', the average height of the stem up to the first pod was $40.1 \mathrm{~cm}$. The lowest average stem height to the first pod was determined for 'Dukat' plants $(34.7 \mathrm{~cm})$.

The average number of pods per plant was 10.5 . Differences in the number of pods between the tested varieties of dry pea were relatively small. The results of the three-year average indicate that the highest number of pods per plant was found in the indeterminate variety 'NS Junior' (12.5), and the lowest average number of pods was found on 'Partner' plants (9.1).

'NS Junior' has the ability to branch, which is confirmed by the obtained results on the number of branches per plant (1.5-1.7), while 'Dukat' and 'Partner' do not have this feature. If a lateral branch appears, this is the result of the influence of a larger vegetation area, i.e. a smaller number of plants than the optimal one (Tab. 1).

The number of pods per plant and the number of grains per pod are the result of the interaction between the genotype of the variety and environmental factors, and the number of plants per unit area. In 'NS Junior', the number of pods per plant ranged from 9.2 in 2010 to 16.8 in 2012, while in 'Dukat' and 'Partner', the number of pods per plant ranged from 8.1 to 11.6 (Tab $1)$. The average number of grains per pod was generally from 4 to 6, which is consistent with the results of other authors (Mihailović, 1994, Mikić, 2012) (Tab. 1).

It is well known that the number of grains per pod is a highly variable yield component. An increase in air temperature during the seed formation stage, a decrease in light intensity, an increase in crop density, as well as a decrease in foliage contribute to an increase in the number of aborted seeds, resulting in fewer seeds per plant (Guilioni et al., 2003). The average number of seeds per pod at the trial level was 4.4. Differences in the number of seeds per pod between the tested varieties of dry pea across years of testing were not significant. The highest number of seeds per pod at the level of the trial was achieved by 'Dukat' (4.9 seeds/pods).

Guilioni et al. (2003) found that seed number per plant, as the most variable component of pea seed yield, was strongly influenced by extremely high temperatures and water stress, especially in the stages from flowering to the onset of grain filling. Extremely high temperatures lead to the decay of generative organs in a very short period of time, while the combination with water stress has a very negative impact on biomass yield and, consequently, on seed yield. In contrast, too high rainfall of unfavorable distribution results in pea lodging and a significant decrease in yield.

The number of grains per plant is the product of the number of pods per plant and the number of grains per pod.

Thousend seed weight (TSW) is a highly heritable property (Mihailović, 1994) and is highly dependent on the genetic composition of the variety (Littleton et al., 1979, Saxena 1980, Poggio et al., 2005). Depending on the genotype of the variety, pea grain differs significantly in size, shape and color. In our three-year trial, the average weight of 1000 grains was $147 \mathrm{~g}$ in 'NS Junior', $232 \mathrm{~g}$ in 'Dukat'and $213 \mathrm{~g}$ in 'Partner' (Tab. 1). Thus, 'NS Junior' is a fine-grained variety, and 'Dukat' and 'Partner' are medium-sized grains (150$250 \mathrm{~g}$ ). It is known that as the number of plants per unit area (in sparse stands) decreases, TSW i.e. seed size increases, and vice versa, in the same variety. TSW directly affects the amount of seeds to be sown per hectare. It should be noted that TSW in most pea genotypes ranges from 40 to 400 grams (Knott, 1987), and that varieties intended for forage production and combined use, which produce high and lush stems and a large proportion of leaves in the total biomass yield, have lower TSW. This is confirmed by our three-year results for 'NS Junior'(Tab. 1). 
The highest absolute grain yield was achieved by the medium-early variety 'Dukat' of the normal-leaf type $(5047 \mathrm{~kg} / \mathrm{ha})$ in 2012 . 'Partner' was least susceptible to seedling and seed fall from pre-harvest pods, as it is of the afila-leaf type and tolerant to lodging, while the lowest yield was observed for the late variety of indeterminate growth ' NS Junior' (2225 $\mathrm{kg} / \mathrm{ha}$ ) in 2012. The increased susceptibility to lodging of varieties of indeterminate tree growth is due to higher plant height, greater internode length and larger plant biomass. As emphasized by Karagić et al. (2008), lodging in pea plants, especially in varieties of indeterminate stem growth, is one of the most significant limiting factors for achieving high seed yields in Serbia's agroenvironmental conditions (Tab. 2).

Table 2.

Grain yield (kg/ha) and crude protein content (\%) of NS pea varieties in the period 2010-2012, Rimski Šančevi

\begin{tabular}{|c|c|c|c|c|c|c|c|c|}
\hline \multirow{2}{*}{ Variety } & \multicolumn{3}{|c|}{$\begin{array}{l}\text { Grain yield } \\
\mathrm{kg} / \mathrm{ha}\end{array}$} & \multirow{2}{*}{$\begin{array}{l}\text { Average } \\
\text { grain yield } \\
\mathrm{kg} / \mathrm{ha}\end{array}$} & \multicolumn{3}{|c|}{$\begin{array}{l}\text { Crude protein content } \\
\%\end{array}$} & \multirow{2}{*}{$\begin{array}{l}\text { Average } \\
\text { crude } \\
\text { protein } \\
\text { content } \\
\%\end{array}$} \\
\hline & 2010 & 2011 & 2012 & & 2010 & 2011 & 2012 & \\
\hline NS Junior & 2977 & 2920 & 2255 & 2717 & 26.4 & 27.9 & 28.7 & 27.6 \\
\hline Dukat & 4893 & 4597 & 5047 & 4846 & 23.1 & 23.7 & 22.6 & 23.1 \\
\hline Partner & 4800 & 4137 & 4627 & 4521 & 23.4 & 24.2 & 21.5 & 23.0 \\
\hline Average & 4223 & 3885 & 3976 & 4028 & 24.2 & 25.3 & 24.3 & 24.6 \\
\hline $\mathrm{CV}$ & 5.4 & 7.4 & 11.5 & 8.5 & 3.8 & 3.6 & 3.7 & 3.7 \\
\hline $\begin{array}{c}\text { LSD } 0.5 \\
0.1\end{array}$ & $\begin{array}{l}368 \\
504\end{array}$ & $\begin{array}{l}479 \\
656\end{array}$ & $\begin{array}{l}801 \\
1098\end{array}$ & $\begin{array}{l}547.5 \\
728.5\end{array}$ & $\begin{array}{l}1.60 \\
2.19\end{array}$ & $\begin{array}{l}1.52 \\
2.09\end{array}$ & $\begin{array}{l}1.56 \\
2.14\end{array}$ & $\begin{array}{l}1.49 \\
1.98\end{array}$ \\
\hline
\end{tabular}

The average three-year grain yield of 'Dukat' (4846 $\mathrm{kg} / \mathrm{ha}$ ) and 'Partner' (4521 kg/ha) was significantly higher than the grain yield of 'NS Junior' (2717 kg/ha), which was expected as 'NS Junior' is intended for combined use (fodder and grain), and 'Dukat' and 'Partner' are typical pea varieties for dry grain production (Tab. 2).

It should be noted that these two varieties of pea produce grain yields of 4.5 to $5.0 \mathrm{t} / \mathrm{ha}$, which clearly indicates their genetic potential, as confirmed by our research. The coefficients of variation across years, for all the varieties tested, were quite low, indicating small fluctuations in grain yield in the experimental years and stability of the tested varieties.

The crude protein content of the grain varied under the influence of climatic conditions. In the late variety of indeterminate stem growth ('NS Junior'), a statistically significantly higher average percentage of crude protein in the grain $(27.6 \%)$ was found compared with the other two tested varieties of shortened stem, 'Dukat' (23.1\%) and 'Partner' (23.0\%) (Tab. 2). It should be noted that 'NS Junior' is the only widely grown variety with such a high content of crude protein in the grain. Certainly, the total protein yield per hectare is the most important indicator of the viability of growing pea for grain, and is the product of grain yield per hectare and the percentage of protein in the grain. Protein yields of 1100 to $1200 \mathrm{~kg} / \mathrm{ha}$ can be considered an excellent result, as confirmed by these test results. The quality of protein in pea grains is excellent because of the good ratio of essential amino acids.

\section{Conclusions}

The most common varieties of spring dry pea in Serbia are 'Partner', 'Dukat' and 'NS Junior'. According to their morphological characteristics and length of the growing season, they belong to different types and groups of varieties.

Created by different breeding methods, they differ significantly in type of stem growth, leaf structure, stem height, susceptibility to lodging, 1000 grain weight, and growing season length.

The obtained results indicate a high genetic potential for grain yield in spring NS varieties of dry pea ( $>5.5 \mathrm{t} / \mathrm{ha}$ ), with a crude protein content of up to $28 \%$. The results obtained indicate the potential of dry pea, as well as the need to expand the growing range in order to increase the stability of protein yield per unit area.

'NS Junior' has the highest content of crude protein in the grain and is a highly adaptable variety that has been maintained for 30 years in wide production.

With a grain yield of $5000 \mathrm{~kg}$ and a protein content of $25 \%$, more than $1200 \mathrm{~kg}$ of crude protein per hectare is provided, which is of particular importance.

\section{Acknowledgments}

This work is part of the TR 31024 project "Increasing the market importance of forage crops by breeding and optimizing seed production technology", funded by the Ministry of Education, Science and Technological Development of the Republic of Serbia, 2011-2019. 


\section{References}

Denarie, J., Debelle, F., Rosenberg, C. (1992). Signaling and host range variation in nodulation. Annual reviews in Microbiology, 46(1), 497-531.

Erić, P, Ćupina, B., Mihailović, V., Mikić, A. (2004). Sortna specifičnost agrotehnike stočnog graška. Zbornik radova Instituta za ratarstvo i povrtarstvo, 40, 405-417.

FAOSTAT (2016). FAO Statistical Databases (FAOSTAT), Food and Agricultural Organization of the United Nations (FAO), Rome, http://faostat.fao.org

Guilioni, L,, Wéry, J., Lecoeur, .J (2003). High temperature and water deficit may reduce seed number in field pea purely by decreasing plant growth rate. Functional Plant Biology, 30(11), 1151-1164.

Heath, M.C., Knott, C.M., Dyer, C.J., Rogers-Lewis, D. (1991). Optimum plant densities for three semileafless combining pea (Pisum sativum) cultivars under contrasting field conditions. Annals of Applied Biology, 118(3), 671-688.

Jovičić, D., Vujaković, M., Milošević, M., Karagić, Đ., TaškiAjduković, K., Ignjatov, M., Mikić, A. (2010). Uticaj zaslanjenosti na klijanje i parametre porasta ponika stočnog graška (Pisum sativum L.). Ratarstvo $i$ povrtarstvo, 47(2), 523-528.

Karagić, Đ., Katić, S., Mihailović, V., Vasiljević, S., Mikić, A., Milić, D. (2008). What a seed producer needs from a plant breeder - the example of Novi Sad (NS) forage legumes varieties. Book of Abstracts of the Second Grain Legumes Technology Transfer Platform (GL-TTP) Workshop, Novi Sad, Serbia, 56-57.

Knott, C. M. (1987). A key for stages of development of the pea (Pisum sativum). Annals of applied Biology, 111(1), 233245.

Littleton, E.J., Dennett, M.D., Elston, J., Monteith, J.L. (1979). The growth and development of cowpea (Vigna unguiculata) under tropical field conditions: 1. Leaf area. The Journal of Agricultural Science, 93(02), 291-307.

Mera, K. (1989). Plant population and spacing for conventional foliage dry pea (Pisum sativum L.), Plaoma, Florette, Agricultura Tecnica (Chile).
Mihailović, V., Mikić, A., Katić, S., Karagić, Đ., Milošević, B. (2010). Potencijal stočnog graška za prinos proteina krme i zrna. Ratarstvo i povrtarstvo, 47(1), 43-48.

Mikić, A., Mihailović, V., Duc, G., Ćupina, B., Eteve, G., LejeuneHenaut, I., Mikić, V. (2007). Evaluation of winter protein pea cultivars in conditions of Serbia. Zbornik Radova, Institut za ratarstvo i povrtarstvo Novi Sad, XI simpozijuma o krmnom bilju Republike Srbije sa međunarodnim učešćem, No. II, 107-112.

Mikić, A., Ćupina, B., Mihailović, V., Krstić, Đ., Đorđević, V., Perić, V., Srebrić, M., Antanasović, S., MarjanovićJeromela, A., Kobiljski, B. (2012). Models and ideotypes for forage legume intercropping in temperate regions. In: Lichtfouse E (ed) Sustainable Agriculture Reviews. Springer, Vol. 11, 161-182.

Moot, D. J., McNeil, D.L. (1995). Yield components, harvest index and plant type in relation to yield differences in field pea genotypes. Euphytica, 86(1), 31-40.

Poggio, S.L., Satorre, E.H., Dethiou, S., Gonzalo, G.M. (2005). Pod and seed numbers as a function of photothermal quotient during the seed set period of field pea (Pisum sativum) crops. European Journal of Agronomy, 22(1), 5569.

Pullan, M.R., Hebblethwaite, P.D. (1990). The interaction between lodging and plant population in combining pea. Annals of Applied Biology, 117(1), 119-127.

Rawal, V., Navarro, D.K. (2019). TheGlobal of Economy Pulses. Food and Agriculture Organization of the United Nations, 174.

Saxena, M.C. (1980). Resent advances in chick pea improvement hyderabad. AP ICRISAT India, 89-96.

Sawicki, J, Boros, L, Wawer, A (2000). The effect of plant densities on agronomic traits of three semi-leafless pea (Pisum sativum L.) genotypes. Biuletyn-Instytutu Hodowli $i$ Aklimatyzacji Roslin, 253-262.

Spies, J.M., Warkentin, T.D., Shirtliffe, S. (2010). Basal branching in field pea cultivars and yield-density relationships. Canadian Journal of Plant Science, 90(5), 679-690.

Yucel, D.O. (2013). Impact of plant density on yield and yield components of pea (Pisum sativum ssp. sativum L.) cultivars. ARPN Journal of Agricultural and Biological Science, 8(2),169-174 